\title{
La responsabilidad del Estado en Argentina y el alcance de la reparación por su actividad lícita*
}

\section{The liability of the State in Argentina and the scope of reparation for its lawful activity}

SUMARIO

Introducción. I. La evolución de la jurisprudencia de la Corte Suprema. a. "Corporación Inversora Los Pinos" (1975). b. "Cantón" (1979). c. "Sánchez Granel" (1984). d “"Motor Once S.A." (1989). e. "Juncalán Forestal" (1989). f. "El Jacaranda S.A." (2005). g. "Zonas Francas Santa Cruz S.A." (2009). h. "Malma Trading S.R.L." (2014). II. La opinión de la doctrina hasta la sanción de las normas bajo análisis. Posturas contrarias y favorables al reconocimiento del lucro cesante. a. Postura contraria al reconocimiento del lucro cesante. 1. Fuerza expansiva de la teoría de la expropiación. Normas de derecho público y privado. 2. Distinción según la naturaleza del derecho lesionado. b. Postura favorable al reconocimiento del daño emergente y el lucro cesante. III. El Código Civil y Comercial. Iv. La ley sobre responsabilidad del Estado. Conclusiones.

RESUMEN

El trabajo examina el alcance de la reparación de los daños ocasionados por el Estado por su actividad lícita. En primer lugar, se estudian los precedentes más importantes de la Corte Suprema sobre el tema y se analiza la opinión de

\footnotetext{
* Doctorando de la Universidad de Buenos Aires, máster en Derecho Constitucional del Centro de Estudios Políticos y Constitucionales (España), especialista en Derecho Administrativo Económico de la Pontificia Universidad Católica Argentina, abogado de la Universidad de Buenos Aires. Profesor auxiliar de Derecho Constitucional en la Universidad de Buenos Aires. Se desempeña profesionalmente en el Juzgado Nacional en lo Contencioso Administrativo Federal n..$^{\circ}$ y es miembro de la Asociación Argentina de Derecho Constitucional. Autor de artículos sobre temas de su especialidad. Contacto: juan@ylarri.com.ar

** Recibido el 2 de febrero de 2016, aprobado el 16 de mayo de 2016.

Para citar el artículo: J. S. YLARRI, La responsabilidad del Estado en Argentina y el alcance de la reparación por su actividad lícita, Derecho del Estado n. ${ }^{\circ} 36$, Universidad Externado de Colombia, enero-junio de 2016, pp. 331-359. Dor: http://dx.doi.org/10.18601/01229893.n36.11
} 
la doctrina. Luego, se analizan las disposiciones del Código Civil y Comercial y de la ley de responsabilidad del Estado recientemente sancionadas. Se concluye que los tribunales de justicia, en un caso particular, podrían declarar la inconstitucionalidad de la ley de responsabilidad del Estado por violar los derechos constitucionales de igualdad y de propiedad.

PALABRAS CLAVE

Acción por responsabilidad, daños y perjuicios, igualdad ante la ley, derecho de propiedad, control jurisdiccional.

\section{ABSTRACT}

The paper examines the scope of reparation for damage caused by the State for its lawful activity. First, we study the most important precedents of the Supreme Court on the subject, and we discuss the opinion of the doctrine. Then, we analyze the provisions of the Civil and Commercial Code, and the liability of the State law recently enacted. We conclude that courts, in a particular case, may declare unconstitutional the law of State liability for violating the constitutional right to equality and property.

\section{KEY WORDS}

Action to establish liability, damages, equality before the law, personal property, judicial review.

\section{INTRODUCCIÓN}

El alcance de la reparación por el actuar legítimo del Estado no ha tenido una solución pacífica en la jurisprudencia ni en la doctrina, en particular por la ausencia de una norma que la regule. Es así que la cuestión ha tomado relevancia nuevamente por la sanción de la ley sobre responsabilidad del Estado. A su vez, el anteproyecto del Código Civil y Comercial contenía disposiciones al respecto, aunque aquella propuesta no fue tenida en cuenta en el Código Civil y Comercial finalmente aprobado por el Congreso de la Nación.

En este contexto, se analiza la evolución de la jurisprudencia de la Corte Suprema de Justicia de la Nación y se estudian las distintas posturas adoptadas por la doctrina. Seguidamente, se aborda de modo particular el texto del anteproyecto del Código Civil y Comercial, y la solución adoptada por la ley sobre responsabilidad del Estado, para finalizar con nuestra opinión personal sobre el tema. 


\section{LA EVOLUCIÓN DE LA JURISPRUDENCIA DE LA CORTE SUPREMA}

La Corte Suprema de Justicia de la Nación ha señalado que el reconocimiento de la responsabilidad estatal por su actividad lícita exige para su procedencia el cumplimiento de ciertos requisitos imprescindibles, que son la existencia de un daño cierto, la relación de causalidad entre el accionar del Estado y el perjuicio, y la posibilidad de imputar jurídicamente esos daños a la demandada $^{1}$. A los mencionados requisitos cabe añadir la necesaria verificación de la existencia de un sacrificio especial en el afectado, como así también la ausencia de un deber jurídico a su cargo de soportar el daño ${ }^{2}$.

En relación a los alcances de la reparación por los daños ocasionados por su actividad lícita, el máximo tribunal a lo largo de los años ha variado su postura. En efecto, como bien lo sostiene Gelli, desde los precedentes más antiguos hasta el precedente "Malma Tradig" de 2014 la Corte Suprema dictó una abundante jurisprudencia cuyo rasgo más saliente fue la fluctuación acerca del alcance de la reparación en materia de responsabilidad del Estado por actos lícitos ${ }^{3}$. A continuación se reseña alguno de los fallos más trascendentes sobre el tema.

\section{a. "Corporación Inversora Los Pinos" $(1975)^{4}$}

En este caso, la mayoría de la Corte Suprema hizo lugar a la demanda deducida para que se condene a la Municipalidad de la Ciudad de Buenos Aires a indemnizar al actor por la revocación de la autorización que le fuera concedida para habilitar un inmueble como hotel alojamiento por horas, y estimó que no era procedente la indemnización del lucro cesante.

De esta forma, el máximo tribunal consideró que el sacrificio impuesto en forma particular a la actora en beneficio de la comunidad no es propio que sea soportado únicamente por aquella, ya que de lo contrario iría en desmedro del principio de igualdad ante la ley y las cargas públicas que consagra el artículo $16 \mathrm{CN}$.

Sin embargo, sostuvo que si bien en el caso el sacrificio de los intereses particulares se hacía en el interés público, sin que paralelamente el patrimonio de la administración se viera acrecentado, solo resultaba atendible el interés

1 Corte Suprema de Justicia de la Nación (Csın), "Tejedurías Magallanes S.A. c/ Administración Nacional de Aduanas", 19/9/1989 (Colección de Fallos de la Corte Suprema [Fallos], t. 312, p. 345), entre otros.

2 CSJn, "Columbia S.A. de Ahorro y Préstamo para la Vivienda c/ Banco Central de la República Argentina”, 19/5/1992 (Fallos: 315:1026).

3 GelLI, M. A. Lectura constitucional de la Ley de Responsabilidad del Estado. Revista Jurídica Argentina La Ley, t. 2014-E, 659.

4 CsJn, "Corporación Inversora Los Pinos S.A. c/ Municipalidad de la Ciudad de Buenos Aires”, 22/12/1975 (Fallos: 293:617). 
negativo, que limita el resarcimiento de los daños que sean consecuencia directa e inmediata de la confianza del actor en que el acto revocado sería mantenido (daño emergente), pero que excluía todo otro valor o ganancia frustrada.

\section{b. "Cantón" (1979)}

El actor sostenía que el Decreto 2118/71, que había prohibido la importación de determinados productos con el objeto de nivelar la balanza de pagos y defender la industria nacional, era contrario a su derecho de comerciar y de propiedad.

La Corte Suprema admitió los agravios del apelante en cuanto perseguían en forma subsidiaria la reparación del daño, hecho que se situaba en el campo de la responsabilidad del Estado por los perjuicios causados por el accionar legítimo de la Administración, admitiendo la posibilidad de exigir la indemnización pertinente teniendo en cuenta las modalidades propias de esa situación.

En este sentido, entendió que la reparación debía atender, ante la falta de normas expresas sobre el punto, al modo de responder establecido en instituciones análogas (art. 16 CC), y aceptó, en la especie, que la expropiación era la que guardaba mayor semejanza en el supuesto planteado, por el ámbito en que se desenvolvía, la finalidad que perseguía y la garantía que protegía. Aclaró, asimismo, que para determinar el perjuicio sufrido resultaban viables aquellas normas, no siendo procedentes las propias del derecho común relativas a la responsabilidad civil.

Por ello, el máximo tribunal entendió que el resarcimiento debía comprender el daño emergente para restaurar el equilibrio patrimonial, con exclusión de las ganancias que podría haber obtenido en la reventa y de todo lucro cesante originado por tal motivo.

\section{c. "Sánchez Granel" $(1984)^{6}$}

La Corte Suprema hizo lugar al resarcimiento por el lucro cesante a favor de la actora a raíz de la rescisión del contrato de obra pública que, por motivos de oportunidad, mérito y conveniencia, había dispuesto su contratante, la Dirección Nacional de Vialidad.

En el voto mayoritario, conformado por los doctores Carrió, Belluscio y Petracchi, se señaló que la legitimidad del proceder del Estado en la resolución unilateral del contrato no lo relevaba de la obligación de resarcir los

5 CSJN, “Canton, Mario Elbio c/ Nación”, 15/5/1979 (Fallos: 301:403).

6 CSJN, "Eduardo Sánchez Granel Obras de Ingeniería S.A.I.C.F.I. c/ Dirección Nacional de Vialidad", 20/9/1984 (Fallos: 306:1409). 
daños que de aquel se hubiesen derivado, y que no podía limitarse al daño emergente con exclusión de la de hacerse cargo del lucro cesante, es decir, de las ventajas económicas esperadas de acuerdo a probabilidades objetivas debida y estrictamente comprobadas.

Asimismo, la Corte Suprema señaló que la indemnización debía ser plena, aclarando que no se refería a la mera posibilidad de ganancias no obtenidas, y que no constituía enriquecimiento sin causa para el acreedor o una sanción para el responsable. Indicó que dicha indemnización podría encontrar obstáculo en razones de fuerza mayor, en el mismo contrato, o en una ley específica que dispusiera lo contrario para algún caso singular. Asimismo, remarcó que el principio jurídico que rige toda indemnización es el de la integridad.

Por el contrario, en el voto minoritario conformado por los doctores Caballero y FAYT se entendió que si bien no había norma que autorice a eximir al Estado de la justa e integral reparación de los perjuicios que causare cuando resolviere unilateral e ilegítimamente un contrato de obra pública, esa ilicitud administrativa no se daba en el accionar de la Dirección Nacional de Vialidad.

Asimismo, se señaló que como la Ley $13.064^{[7]}$ era la que regía los contratos de obra pública, aunque no contenía una norma que contemplara específicamente la situación del caso, sí contenía regulación sobre situaciones análogas que excluían el reconocimiento de lucro cesante.

\section{d."Motor Once S.A." (1989) $)^{8}$}

El máximo tribunal, mediante el voto de los jueces Belluscio, FAYt y BACQUÉ, se remitió a lo dictaminado por la procuradora fiscal Reiriz y revocó la sentencia de la instancia anterior en cuanto había hecho lugar al reconocimiento de lucro cesante. La actora había iniciado demanda contra la Municipalidad de la Ciudad de Buenos Aires, por nulidad del acto que había dispuesto el cese de expendio de combustible en el negocio que explotaba, impugnando la legitimidad de la norma que le daba sustento. En efecto, la Ordenanza 27.455 había modificado el cuadro de prevenciones contra incendio del Código de Edificación, prohibiendo destinar un inmueble a vivienda en los casos en que en el piso bajo se encontrara una estación de servicio.

La procuradora fiscal entendió que ante la ausencia de una solución normativa singularizada para este tipo de responsabilidad estatal, debía recurrirse a los principios de leyes análogas (art. $16 \mathrm{CC}$ ). En este sentido, señaló que la norma que guardaba mayor analogía con la situación discutida en autos era la Ley Nacional de Expropiaciones $21.499^{[9]}$, resaltando que la responsabi-

7 Boletín Oficial de la República Argentina (B.O.) 28/10/1947.

8 CSJN, "Motor Once, SAC e I. c/ Municipalidad de la Ciudad de Buenos Aires", 9/5/1989 (Fallos: 312:649).

9 B.O. 21/1/1977. 
lidad extracontractual del Estado por actividad lícita no podía disciplinarse por normas de derecho privado, porque ante el Estado actuando conforme a derecho fallan todos los preceptos sobre actos ilícitos.

Así, indicó que se había producido una legítima afectación de los derechos de un particular, sacrificados por razones de interés público.

\section{e. “Juncalán Forestal” (1989) $)^{10}$}

La Dirección Hidráulica provincial había realizado trabajos en el canal aliviador del Río Quinto, consistentes en la apertura de brechas para desviar las aguas, que produjeron inundaciones en el establecimiento del actor. Por lo tanto, demandó a la provincia de Buenos Aires por daños y perjuicios. El máximo tribunal hizo lugar a la demanda y al reclamo de lucro cesante ${ }^{11}$.

En el voto de los doctores Petracchi y Belluscio se reiteró lo expresado en el precedente "Sánchez Granel", en cuanto a que los actos lícitos producidos por el Estado no lo relevan de la obligación de resarcir los perjuicios sufridos por particulares que se hubiesen derivado de aquellos, por lo que no podían limitarse al daño emergente con exclusión de lucro cesante, es decir, las ventajas económicas esperadas de acuerdo a probabilidades objetivas debida y estrictamente comprobadas, por lo que ese principio se traducía en el derecho a una indemnización plena.

A su vez, se indicaron dos razones por las cuales no cabía omitir la reparación mediante la aplicación analógica de la ley de expropiaciones, ya que no era dable extender la norma legal que excluye ese resarcimiento a otros supuestos diversos. En primer lugar, porque la expropiación presupone una privación constitucional del derecho de propiedad mediante leyes del Congreso valorativas de la utilidad pública del objeto de desapropio y, en segundo lugar, porque la aplicación analógica no parecía hermenéutica apropiada cuando el término de comparación que tiene reconocimiento legal importa una solución de excepción.

El doctor FAYT, en su voto, estimó que no debería acudirse al instituto de la expropiación que veda la reparación del lucro cesante, ya que a la luz del caso particular esa solución tropezaba con obstáculos insalvables. En efecto, consideró que la actora no había sido privada de su propiedad, sino únicamente de su uso, y señaló que en la expropiación aquellos intereses se calculaban sobre el monto de la indemnización, que en el caso no estaba representado por el valor del campo inundado, por lo que si se computaran

10 CSJn, "Jucalán Forestal, Agropecuaria SA. c/ Buenos Aires, Provincia de s/ daños y perjuicios", 23/11/1989 (Fallos 312:2266).

11 Respecto del alcance de la reparación en relación con inundaciones generadas por obras públicas, ver BoRETTO, M. Responsabilidad del Estado por actividad lícita: obra pública e inundaciones. ¿La reparación del 'lucro cesante'? Revista Jurídica Argentina El Derecho, $4 / 11 / 2015,1$ ss. 
sobre el resarcimiento que en el caso se otorgaba en concepto de daño emergente, no compensarían la privación de capital de cuyo uso ha sido impedido al demandante.

Por ello, sostuvo que la justa solución del conflicto pasaba por examinar las reglas concernientes al instituto de la ocupación temporánea, ya que ni lógica ni axiológicamente correspondía que la actora soporte el sacrificio desmedido que importaría privarla de todo resarcimiento por la exclusión en el uso de su propiedad que se había visto obligada a soportar.

\section{f. “El Jacaranda S.A.” (2005) ${ }^{12}$}

Por Decreto 2686/83 se había adjudicado a la actora la licencia para la explotación de una estación de radiofusión sonora. Posteriormente, por Decreto 899/94 $4^{[13]}$ se dejó sin efecto la adjudicación a la actora de la explotación de la frecuencia. La Corte Suprema confirmó la sentencia de la instancia anterior que rechazó la demanda de nulidad de acto administrativo y del resarcimiento de daños y perjuicios.

En el voto mayoritario, integrado por los doctores Petracchi, Belluscio, Maqueda, ZaFFARoni, LorenzetTI y Argibay, se indicó que la actividad lícita de la autoridad administrativa, aunque inspirada en propósitos de interés colectivo, se constituía en causa eficiente de un perjuicio para particulares, cuyo derecho se sacrificaba por aquel interés general, y que esos daños debían ser atendidos en el campo de la responsabilidad del Estado por su obrar lícito ${ }^{14}$.

También se recordó que los jueces deben actuar con suma prudencia cuando se trata de resarcir daños causados por actos administrativos dispuestos por razones de interés general, verificando si tales daños efectivamente se han producido y si son consecuencia directa e inmediata del obrar del Estado ${ }^{15}$. Asimismo, se señaló que la extensión del resarcimiento debía atender a las características particulares de cada situación, entendiendo que no hay, como principio, fundamento para limitarlo al daño emergente con exclusión del lucro cesante; $y$, analizando la concreta prueba producida en la causa, entendió que no se había probado en el juicio la concreta privación a la actora de ventajas esperadas de acuerdo a probabilidades objetivas estrictamente comprobadas ${ }^{16}$.

12 CSJN, "El Jacarandá S.A. c/ Estado Nacional s/ juicios de conocimiento", 28/5/2005 (Fallos 328:2654).

13 B.O. 14/6/1994.

14 Ver csjn, "Canton" (Fallos: 301:403); "Lovardo, Salvador c/ Municipalidad de Vicente López”, 15/3/1983 (Fallos: 305:321); y "Sánchez Granel” (Fallos: 306:1409).

15 CSJn, "Galanti, Carlos Alberto c/ Municipalidad de la Ciudad de Buenos", 22/12/1987 (Fallos: 310:2824).

16 Con cita del precedente "Sánchez Granel" (Fallos 306:1409), considerandos 4 y 5; "Cachau, Oscar José c/ Bs. As. Pcia. de s/ daños y perjuicios”, 16/6/1993 (Fallos: 316:1335), considerando 20 . 
Por su parte, la doctora Highton de Nolasco, en su voto, indicó que la indemnización en casos como ese debía ceñirse, en principio, al daño emergente. En relación a la admisión del lucro cesante en la indemnización debida por el Estado, recordando que esos daños debían ser atendidos en el campo de la responsabilidad por su obrar lícito, estimó que, ante la ausencia de una solución normativa singularizada para este tipo de responsabilidad estatal, era adecuado recurrir a los principios de leyes análogas, toda vez que la regla de interpretación prevista en el artículo 16 CC excedía los límites del ámbito del derecho privado y se proyecta como un principio general, vigente en todo el orden jurídico interno ${ }^{17}$.

De esta forma, entendió que esa analogía debía fundarse en principios de derecho público, toda vez que la actividad legítima del Estado, aun cuando provoque daños, tiene una finalidad típica de interés público, que se encuentra ausente en las normas regulatorias de derecho común que persiguen la composición equitativa de conflictos en los que se involucran intereses privados ${ }^{18}$. Así, afirmó que a diferencia del derecho privado, donde rigen criterios de justicia conmutativa, en el derecho público se aplican, en principio, criterios de justicia distributiva ${ }^{19}$.

También, estableció la diferencia básica entre la regulación privatista y la publicista: mientras la primera regula relaciones entre particulares fundamentadas sobre la base de la conmutatividad, la segunda regula las relaciones entre el todo (la comunidad representada por la autoridad) y la parte (los ciudadanos, ya sea individualmente o agrupados en asociaciones o cuerpos intermedios) según criterios de distribución.

Entonces, examinando las normas que fijan pautas indemnizatorias y que guardan mayor analogía con la situación discutida en la causa, encontró la solución en la Ley Nacional de Expropiaciones 21.499, es decir, en la norma legal típica que autoriza las intromisiones del Estado en la propiedad de los administrados, cada vez que el interés público las exija, ya que sin esas intromisiones el Estado no es capaz de cumplir sus funciones ${ }^{20}$. Recordó asimismo que el criterio de la exclusión del lucro cesante también ha sido receptado en un vasto conjunto de normas de derecho público ${ }^{21}$.

17 CSJN, "Laplacette, Juan su sucesión y otros c/ Prov. de Bs. Aires", 1943 (Fallos: 195:66); "Canton" (Fallos: 301:403); "Sánchez Granel" (Fallos: 306:1409), disidencia de los doctores Caballero y FAYT; "Motor Once" (Fallos: 312:659), dictamen de la Procuradora Fiscal al que la Corte remitió; "Jucalán Forestal" (Fallos: 312:2266), voto del doctor FAYT, entre otros.

18 "Canton" (Fallos: 301:403); "Motor Once" (Fallos: 312:659), dictamen de la Procuradora Fiscal al que la Corte remitió.

19 Conf. Marienhoff, M. S. El lucro cesante en las indemnizaciones a cargo del Estado (lo atinente a la revocación de actos o contratos administrativos por razones de oportunidad, mérito o conveniencia). Revista Jurídica Argentina El Derecho, t. 114, 949.

20 "Canton" (Fallos: 301:403); "Motor Once" (Fallos: 312:659), dictamen de la Procuradora Fiscal al que la Corte remitió.

21 Cita, p. ej., las leyes 12.910 (art. 5), 13.064 (arts. 30, 38 y 54 inc. f), 23.554 (art. 35), 
En relación al argumento de que el instituto de la expropiación supondría una restricción constitucional al derecho de propiedad mediante una ley del Congreso, entendió que aquello no impedía la aplicación analógica de la ley de expropiaciones a casos como el que se analizaba. En efecto, estimó que, admitida la facultad de la administración de limitar el derecho de los particulares fundándose en propósitos de bien común, sería razonable que las consecuencias de su ejercicio sean similares a las que se producen cuando dicha limitación se origina en una ley, ya que no advierte una diferencia sustancial entre una actividad lícita del Estado basada en ley y una basada en normas de inferior jerarquía, en un todo de acuerdo con la relación de que se trate. Por el contrario, lo que debe caracterizar a todos los supuestos de limitación de la propiedad por razones de interés público (sea por decisión del Congreso o de la administración) es la ausencia de antijuridicidad.

Por último, señaló que resultaba inadecuada la teoría de la responsabilidad civil para fundamentar la procedencia de la responsabilidad estatal por actuación legítima, ya que cuando el Estado actúa conforme a derecho fallan todos los preceptos sobre los actos ilícitos contemplados en las disposiciones civiles.

\section{g. "Zonas Francas Santa Cruz S.A.” (2009)22}

Mediante Decreto 520/95 ${ }^{[23]}$ el Poder Ejecutivo Nacional había autorizado la venta al por menor de mercaderías de origen extranjero provenientes de las zonas francas de Río Gallegos y Caleta Olivia, en diversas localidades de la provincia de Santa Cruz. La actora ganó la licitación pública convocada por la provincia de Santa Cruz para el establecimiento y explotación de las dos zonas francas mencionadas y, posteriormente, el Poder Ejecutivo Nacional dictó el Decreto 1583/96 $6^{[24]}$, que dispuso dejar sin efecto el Decreto 520/95 por razones de oportunidad, mérito y conveniencia, por lo que lo impugnó por ser nulo e inconstitucional. La Corte Suprema revocó parcialmente la sentencia de la instancia anterior, que había hecho lugar a la demanda de daños y perjuicios, solamente en lo referente al monto de la indemnización.

En este sentido, en el voto de doctores Lorenzetti, Fayt, Petracchi, MAQUEDA y ARGIBAY se recordó, en primer lugar, que para que se configure la responsabilidad por daños y perjuicios son requisitos ineludibles la existencia de un daño cierto, la relación de causalidad entre la conducta fundamento del reclamo y el perjuicio invocado, y la posibilidad de imputar jurídicamente

el derogado decreto 5720/72 (inc. 88), decretos 436/00 (art. 96), 1023/01 (art. 12, inc. d) y las leyes 25.344 (art. 26) y 25.453 (art. 11).

22 CSJn, "Zonas Francas Santa Cruz S.A. c/ Estado Nacional - P.E.N. - Dto. 1583/96 s/ daños y perjuicios", 9/6/2009 (Fallos 332:1367).

23 B.O. $2 / 10 / 1995$.

24 B.O. 6/1/1997. 
esos daños a la demandada ${ }^{25}$; y concluyó que la actora no había acreditado los daños solicitados en concepto de lucro cesante, con el grado de certeza necesario para la procedencia de su reparación ${ }^{26}$. Asimismo, se afirmó que quien invoca ciertos hechos como fundamento de su pretensión tiene la carga de acreditarlos ${ }^{27}$, y si no logra cumplir con esa carga mediante la actividad probatoria desarrollada durante el juicio, corre el riesgo de que su reclamo sea denegado.

Por su parte, la doctora Highton de Nolasco entendió que se debía revocar la sentencia en cuanto condenaba al Estado Nacional al pago del rubro lucro cesante, remitiéndose a sus fundamentos y conclusiones desarrollados en el caso "El Jacarandá S.A." antes mencionado, en la que concluyó que la condena al Estado por los daños y perjuicios ocasionados por su actividad lícita no alcanzaba la reparación por lucro cesante.

\section{h. "Malma Trading S.R.L.” $(2014)^{28}$}

Mediante Resolución 790/92 ${ }^{[29]}$ dictada por el entonces Ministerio de Economía Obras y Servicios Públicos se prohibió la importación de una cantidad determinada de motociclos usados. La accionante promovió demanda contra el Estado Nacional tendiente a obtener la indemnización de los daños derivados de aquella decisión. De manera subsidiaria, fundó su reclamo en la responsabilidad del Estado por su actividad legítima.

La Corte Suprema, con el voto de los doctores Highton de Nolasco, FAYT y MAQUEDA, revocó la sentencia del tribunal a quo e hizo parcialmente lugar a la demanda ${ }^{30}$. En lo que respecta a la responsabilidad del Estado por su actividad lícita, el máximo tribunal sostuvo que es esencial a esta clase de responsabilidad que la actividad administrativa se constituya en causa eficiente de un perjuicio particular para conseguir -a través de él-finalidades de interés general o colectivo, y que la actividad del Estado debe haber producido una lesión a una situación jurídicamente protegida. En este contexto, estimó

25 CSJn, "Agencia Marítima Rioplat SA. c/ cap. y/o arm. y/o prop. bq. Eleftherotria s/ ordinario", 10/12/1992 (Fallos: 315:2865); "Viento Norte de herederos de Bruno Corsi SRL. c/ Santa Fe, Provincia de s/ ordinario", 4/3/1997 (Fallos: 320:266); "Serradilla, Raúl Alberto c/ Mendoza, Provincia de y otro s/ daños y perjuicios", 12/6/2007 (Fallos: 330:2748).

26 CSJN, "Viento Norte de herederos de Bruno Corsi SRL." (Fallos: 311:2683); "Videla Cuello, Marcelo suc. de c/ La Rioja, Prov. de s/ daños y perjuicios", 16/3/1989, (Fallos: 312:316), entre otros.

27 Art. 377 del Código Procesal Civil y Comercial de la Nación.

28 CSJn, "Malma Trading S.R.L. c/ Estado Nacional-Ministerio de Economía y Obr. y Serv. Publ. s/ proceso de conocimiento", 15/5/2014 (causa M.1378. XLVII, ROR).

29 B.O. 2/7/1992.

30 Sobre este caso, ver el comentario de PizArro, R. D. Responsabilidad del Estado por actos lícitos. Consecuencias 'normales' y 'anormales' de su actividad. Revista Jurídica Argentina La Ley, t. 2014-C, 262. 
que correspondía reconocerle el rubro "anticipo a cuenta no recuperado" en tanto de las constancias de las actuaciones se desprendía que la empresa pagó un $10 \%$ del valor integral del contrato a cuenta del precio total y como principio de ejecución, que no fue por ella recuperado, en la medida en que el contrato no pudo terminar de ejecutarse.

Sin embargo, rechazó el reconocimiento de los perjuicios que la actora manifestó haber sufrido, en concepto de daño emergente (inversiones en publicidad, inversiones en infraestructura) ya que constituían riesgos propios del giro comercial, circunstancia frente a la cual cobraba mayor virtualidad el principio según el cual en nuestro ordenamiento jurídico no existe un derecho adquirido al mantenimiento de las leyes o reglamentaciones ni a su inalterabilidad ${ }^{31}$. En lo que respecta al lucro cesante manifestó que "no se encuentra acreditada la condición de especialidad en los términos de la doctrina anteriormente señalada". Asimismo, el voto mayoritario puso de relieve que "la jueza Highton de Nolasco expresa que, conforme a los fundamentos desarrollados en su voto en la causa 'El Jacarandá' (Fallos: 328:2654), corresponde rechazar la pretensión de que se repare el lucro cesante; y a mayor abundamiento agrega que, en el caso, tal pretensión igualmente debe ser desestimada por no haberse demostrado la condición de especialidad mencionada en el considerando anterior".

Por otro lado, el doctor LoRENZETTI en su voto sostuvo, por un lado, que correspondía hacer lugar a la demanda en relación al "anticipo a cuenta no recuperado", en tanto reunía las condiciones de especialidad necesarias, ya que se trataba de un daño sufrido específicamente por esta importadora, sin que exista el deber jurídico de su parte de soportarlo. Por el contrario, precisó que "frente a la excepcionalidad de este tipo de responsabilidad, el resto de los perjuicios que la recurrente manifiesta haber sufrido (inversiones en publicidad, inversiones en infraestructura) constituyen riesgos propios del giro comercial" ${ }^{2}$.

31 Con cita de los precedentes "De Milo, Ernesto N. c/ Nación”, 1967 (Fallos: 267:247); “Kremer y Kramer Hnos. c/ Nación”, 1967 (Fallos: 268:228); “Cooperativa Ltda. de Enseñanza, Instituto Lomas de Zamora c/ Nación", 1975 (Fallos: 291:359); "Santina, Felipa N. c/ Caceres, Néstor C.”, 1978 (Fallos: 300:61); "Neville, Jorge Andrés c/ Banco Popular Argentino S.A.”, 1986 (Fallos: 308:1361), entre muchos otros.

32 Asimismo, cabe destacar que el juez LoRenzetTI precisó que en tanto en el caso se presentaba un supuesto específico de responsabilidad del Estado por actos lícitos, había que tener en cuenta dos principios: "El primero es el tradicionalmente reconocido, tanto en nuestro ordenamiento como en el derecho comparado, referido a que no existe un derecho adquirido al mantenimiento de las leyes o reglamentaciones ni a su inalterabilidad (Fallos: 267:247; 268:228; 291:359; 300:61; 308:1361 entre muchos otros). La razonabilidad del mismo es evidente porque, de lo contrario, el derecho no podría adaptarse a los cambios ni la gobernabilidad sería posible.

"El segundo, implica que las decisiones, aún legítimas, deben tener un grado de generalidad suficiente como para no afectar intereses particulares con desigual reparto de las cargas públicas. El trato igualitario frente a los sacrificios que demanda la gobernabilidad, es una regla constitucionalmente admitida. A ello cabe agregar que, cuando se producen cambios abruptos 
Finalmente, resta destacar que en su disidencia el doctor PeTRACCHI manifestó que el accionante no había demostrado que la normativa impugnada le hubiera generado daños que, por constituir consecuencias anormales, es decir, que van más allá de lo que es razonable admitir en materia de limitaciones al ejercicio de derechos patrimoniales, significasen un verdadero sacrificio desigual. En este contexto, recordó que la Corte Suprema ha dicho que "la admisión de la doctrina de la responsabilidad estatal por los daños derivados de su actividad lícita no ha de ser entendida como dirigida a instituir en este ámbito un régimen de responsabilidad, de conformidad con el cual bastaría la mera acreditación de la existencia de nexo causal suficiente entre la actividad legítima de los órganos estatales y los perjuicios de cualquier orden que experimentasen los particulares, para suscitar la obligación de indemnizarlos" ${ }^{\prime 3}$.

II. LA OPINIÓN DE LA DOCTRINA HASTA LA SANCIÓN DE LAS NORMAS BAJO ANÁLISIS. POSTURAS CONTRARIAS Y FAVORABLES AL RECONOCIMIENTO DEL LUCRO CESANTE

Dentro de la responsabilidad del Estado por su actividad lícita se pueden distinguir tres áreas de la intervención estatal en la economía, manifestada en el dictado de distintas regulaciones definidas de la siguiente forma: la relativa a regulaciones urbanísticas, la suscitada por obras públicas en general, y otra materia bancaria, financiera o cambiaria ${ }^{34}$.

que inciden sobre las transacciones comerciales en curso se afecta la seguridad jurídica. En este sentido, la gobernabilidad requiere de un mínimo de previsibilidad para que los ciudadanos actúen sobre la base de la confianza, disminuyendo los costos de las transacciones y beneficiando a los consumidores".

33 Conf. csjn, "Román sac. c/ Estado Nacional (Ministerio de Educación y Justicia s/ cobro de pesos", 13/10/1994 (Fallos: 317:1233); y "Pistone, Ciro Alberto c/ Estado Nacional s/ daños y perjuicios", 29/5/2007 (Fallos: 330:2464).

Sobre el caso se ha dicho que "mientras el razonamiento de Highton DE Nolasco en 'El Jacarandá' (que reitera en 'Malma Trading') se construye desde el croquis del derecho privado; el de la mayoría y especialmente el de LORENZETTI se elaboran a partir de una perspectiva más constitucional y de derecho público, asumiendo que el Estado, por su rol, debe avanzar en la toma de decisiones que persiguen propósitos colectivos, pero esta elemental premisa de la gobernabilidad no habilita el atropello a derechos individuales, que pueden ser modificados, a cambio de una compensación pecuniaria, por imperio del art. 17 de la C.N. Dicho en otras palabras, nadie tiene derecho adquirido a la inamovilidad de las leyes, pues la inercia atenta contra la eficiente gestión de gobierno, que requiere constantes adecuaciones a los nuevos escenarios sociales, económicos y políticos; pero esas adaptaciones deben ser igualitarias para todos so pena de reparación al sujeto singularmente perjudicado" (CATALANO, M. Nueva Ley de Responsabilidad del Estado. Análisis de su articulado en relación a la jurisprudencia de la Corte y al proyecto de la Comisión de Reformas al Código Civil. Revista Jurídica Argentina La Ley, Suplemento Responsabilidad Civil y Seguros, 2014-XII, p. 5 ss.).

34 CAPUTI, M. C. La responsabilidad del Estado en Argentina - Una reseña panorámica de sus principales cuestiones en la actualidad. Revista de Derecho Público. Editorial Jurídica Venezolana. Vol. 117, enero-marzo 2009. 
Hasta la sanción de la ley sobre responsabilidad del Estado, en relación al tema del alcance de la reparación por la actuación lícita del Estado, Coviello admitía que no se había despejado un definido criterio, aunque estimaba que la Corte Suprema se inclinaba por la admisión del lucro cesante ${ }^{35}$.

Por su parte, MARIENHOFF señalaba que se trata de una cuestión de fundamental importancia, que no había sido debidamente aclarada por la doctrina, y menos aún por la legislación ${ }^{36}$. Sostenía que la jurisprudencia de la Corte Suprema al respecto era contradictoria, ya que no respondía a conceptos claros, precisos y aceptables. Por ejemplo, entendía que en el caso "Sánchez Granel" se había hecho lugar al pago del lucro cesante, cuando en su opinión no correspondía, y en "Motor Once" se había rechazado, considerándolo errado, ya que el caso requería otra solución por la índole del derecho ahí agraviado $^{37}$.

Sentado esto, es de señalar que cabe distinguir el alcance de la reparación en función de que se trate de un caso de responsabilidad ilícita o lícita. Si se trata de la reparación de daños por la actividad ilícita del Estado, la misma debe ser plena, por lo que incluye el lucro cesante. Sin embargo, se ha dicho que debe establecerse con claridad los límites a la responsabilidad del Estado por su actividad lícita, ya que de otra forma la vida social no sería posible ${ }^{38}$.

Para que se configure el supuesto de responsabilidad del Estado es necesario que se den los requisitos de existencia de daño cierto, la relación de causalidad entre el accionar del Estado y el perjuicio, y la posibilidad de imputar jurídicamente esos daños a la demandada. La reunión de esos requisitos es condición indispensable cualquiera sea su origen, sea una ley, un contrato o un acto administrativo, una actuación material o una omisión, ya se trate de una actividad lícita o ilícita ${ }^{39}$.

\section{a. Postura contraria al reconocimiento del lucro cesante}

En lo que respecta a la postura contraria al reconocimiento del lucro cesante por la actividad lícita del Estado, su análisis se centrará en dos argumentos. Por un lado, se examinará la llamada "fuerza expansiva" de la teoría de la

35 Coviello, P. J. J. La responsabilidad del Estado por su actividad lícita. Revista Jurídica Argentina El Derecho. Suplemento Administrativo, 29/8/2000.

36 MARIENHOFF. El lucro cesante en las indemnizaciones, cit., 949.

37 Marienhoff, M. S. Nuevamente acerca del lucro cesante en las indemnizaciones a cargo del Estado. Revista Jurídica Argentina La Ley, t. 1991-C, p. 1080.

38 De Estrada, J. R. Responsabilidad del Estado por actos legislativos y discrecionales (fundamentos y límites de la responsabilidad por actividad estatal conforme a derecho). Revista Jurídica Argentina El Derecho, t. 102, 839.

39 Lima, F. J. y SAMA, M. A. La responsabilidad del Estado por su accionar lícito: los requisitos para su procedencia. Revista Jurídica Argentina El Derecho, t. 150, 97. 
expropiación. Por otro lado, se hará referencia a la distinción efectuada por la doctrina en relación a la naturaleza del derecho lesionado.

\section{Fuerza expansiva de la teoría de la expropiación. Normas de derecho público y privado}

Hasta la sanción de la ley sobre responsabilidad del Estado se discutía si los principios de expropiación eran de aplicación, a falta de norma que expresamente prevea el caso, a todos los supuestos en los que el Estado, en ejercicio regular de la función administrativa, lesionaba derechos de administrados, causando de esa forma perjuicios que estos no tienen obligación de soportar ${ }^{40}$. COMADIRA estimaba que era conducente la extensión a las situaciones de responsabilidad por obrar estatal lícito, la teoría de la expropiación, separándose de una segunda posición que no acepta la mencionada fuerza expansiva y que se encuadra, fuera de los institutos propios del derecho público, en el marco de la reglamentación legal privada del derecho de propiedad que resulta del sistema de la responsabilidad civil ${ }^{41}$.

De esta forma, entendía que la reparación por el daño causado al administrado, en el ejercicio de una actividad lícita, encuentra su fundamento en el derecho de propiedad, a la luz del principio de igualdad ante la ley y las cargas públicas (arts. 16 y $17 \mathrm{CN}$ ). Por ello, el derecho de propiedad queda comprometido, toda vez que el accionar legítimo estatal que el administrado debe tolerar, genera un daño especial, cuyas consecuencias no es lícito que este soporte en beneficio común sin ser indemnizado. Por lo tanto, de no admitirse la reparación en estas situaciones quedaría violado el principio de igualdad ante la ley.

Sin embargo, el autor citado resalta que la Constitución justifica la indemnización, pero no su alcance. Afirma que si bien el artículo $17 \mathrm{CN}$ tutela el derecho de propiedad, no se puede extraer de su texto una presunta obligación de reparación integral en cualquier supuesto de responsabilidad por daño ${ }^{42}$.

La Convención Americana de Derechos Humanos, Pacto de San José de Costa Rica, en su artículo 21 sobre el derecho a la propiedad privada, en su inciso 2 preceptúa que "ninguna persona puede ser privada de sus bienes, excepto mediante el pago de indemnización justa, por razones de utilidad pública o de interés social y en los casos y según las formas establecidas por la ley", con lo cual se puede observar que no fija de antemano el alcance de la reparación, y que puede variar según cada legislación, sin perjuicio de

40 Comadira, J. R. Derecho Administrativo. Buenos Aires: Abeledo-Perrot, 1996, cap. XIV: Improcedencia del lucro cesante en casos de responsabilidad del Estado por obrar administrativo lícito: fuerza expansiva de los principios de la expropiación, 415-416.

41 Ibíd., 421-422.

42 Ibíd., 436. 
que debe ser justa, y de que su finalidad ha de perseguir la utilidad pública o el interés social.

En cuanto a las normas de derecho público, el artículo 18 de la Ley Nacional de Procedimientos Administrativos $19.549^{[43]}$ habla de indemnizar al administrado, pero no se refiere al alcance de esta reparación. Dispone que el acto administrativo regular, del que hubieren nacido derechos subjetivos a favor de los administrados, "también podrá ser revocado, modificado o sustituido por razones de oportunidad, mérito o conveniencia, indemnizando los perjuicios que causare a los administrados".

El artículo 10 de la Ley Nacional de Expropiaciones 21.499 sí prevé la extensión resarcitoria, limitándola al daño emergente. Así, dispone que "la indemnización sólo comprenderá el valor objetivo del bien y los daños que sean una consecuencia directa e inmediata de la expropiación. No se tomarán en cuenta circunstancias de carácter personal, valores afectivos, ganancias hipotéticas, ni el mayor valor que pueda conferir al bien la obra a ejecutarse. No se pagará lucro cesante. Integrarán la indemnización el importe que correspondiere por depreciación de la moneda y el de los respectivos intereses".

Entonces, al excluir el lucro cesante, Comadira entendía que el artículo gozaba, en razón de la coincidencia estatal por la actividad lícita, de la suficiente "fuerza expansiva" como para proyectar sus alcances de modo directo a toda situación indemnizatoria generada por el actuar administrativo regular ${ }^{44}$.

Entre otras normas de derecho público que no reconocen el rubro lucro cesante cabe mencionar la primera Ley de Expropiaciones 189, la Ley de Obras Públicas $12.910^{[45]}$, la Ley $13.064^{[46]}$, el Reglamento de Contrataciones del Estado Decreto 5720/72 ${ }^{[47]}$, la Ley 23.554 que establece las bases jurídicas,

43 B.O. 27/4/1972.

44 COMADIRA, ob. cit., 439.

45 B.O. 19/5/1947. Art. 5: "En los casos en que se encontrasen total o parcialmente paralizadas las obras y sin perjuicio de lo establecido en el artículo $1 .^{\circ}$ con respecto a la parte de obra ejecutada, se examinará atendiendo a las causas particulares de la paralización, la posibilidad de proseguirlas mediante modificaciones en su estructura técnica, reajuste de precios y condiciones, prórrogas de plazos y otras medidas; o bien, si ello no fuera viable, se procederá a la rescisión de los respectivos contratos sin aplicación de penalidades.

"En este último caso, no le será reconocida a los empresarios ninguna indemnización en concepto de lucro cesante por la parte de obra que se deja de ejecutar".

46 B.O. 28/10/1947. El artículo 54 señala que, "producida la rescisión del contrato en virtud de las causales previstas en el artículo anterior, ella tendrá las siguientes consecuencias: [...] f) No se liquidará a favor del contratista suma alguna por concepto de indemnización o de beneficio que hubiera podido obtener sobre las obras no ejecutadas".

47 B.O.31/8/1972. Dentro de las causas de rescisión que otorgan derecho al adjudicatario, el inciso 88 señala que "cuando el Estado rescinda un contrato por una causa justificada, no prevista en este reglamento, salvo el apartado h) del inciso 54, el adjudicatario tendrá derecho a que se le reconozcan los gastos directos e improductivos en que probare haber incurrido con posterioridad a la adjudicación y con motivo del contrato, pero no se hará lugar a reclamación alguna por lucro cesante o por intereses de capitales requeridos para financiación. Corresponderá, 
orgánicas y funcionales fundamentales para la preparación, ejecución y control de la defensa nacional ${ }^{48}$, el Régimen de Contrataciones de la Administración Nacional aproada por Decreto $1023 / 01^{[49]}$, y su reglamentación aprobada por el Decreto 893/12[50].

Por otro lado, en lo que respecta al derecho civil, cabe señalar que el nuevo Código Civil y Comercial consagra la indemnización integral para caso de incumplimiento obligacional y derivados de responsabilidad por actos ilícitos. En este sentido, su artículo 1738 dispone: "Indemnización. La indemnización comprende la pérdida o disminución del patrimonio de la víctima, el lucro cesante en el beneficio económico esperado de acuerdo a la probabilidad objetiva de su obtención y la pérdida de chances. Incluye especialmente las consecuencias de la violación de los derechos personalísimos de la víctima, de su integridad personal, su salud psicofísica, sus afecciones espirituales legítimas y las que resultan de la interferencia en su proyecto de vida". A su vez, el artículo 1742 establece: "Atenuación de la responsabilidad. El juez, al fijar la indemnización, puede atenuarla si es equitativo en función del patrimonio del deudor, la situación personal de la víctima y las circunstancias del hecho. Esta facultad no es aplicable en caso de dolo del responsable" 51.

Por su parte, el artículo 1261 del Código Civil y Comercial establece: "Desistimiento unilateral. El comitente puede desistir del contrato por su sola voluntad, aunque la ejecución haya comenzado; pero debe indemnizar

también, el reconocimiento del valor del pliego de bases para la licitación si el mismo debió ser adquirido".

48 B.O. 5/5/1988. Art. 35: "La obligación prevista en el artículo anterior será carga pública irrenunciable. Si ese aporte implicara gastos o prestación de servicios se determinará administrativamente la indemnización o remuneración correspondiente, no pudiendo en ningún caso reconocer el lucro cesante. En caso de desacuerdo, el monto será fijado judicialmente a pedido de la parte interesada".

49 B.O. 16/8/2001. Art. 12, inc. b), segundo párrafo: "La revocación, modificación o sustitución de los contratos por razones de oportunidad, mérito o conveniencia, no generará derecho a indemnización en concepto de lucro cesante".

50 B.O. 14/6/2012. Art. 121: "Rescisión sin culpa de las partes. La revocación, modificación o sustitución de los contratos por razones de oportunidad, mérito o conveniencia, no generará derecho a indemnización en concepto de lucro cesante, sino únicamente a la indemnización del daño emergente, que resulte debidamente acreditado".

51 El antiguo Código Civil establecía en su artículo 1069 que "el daño comprende no sólo el perjuicio efectivamente sufrido, sino también la ganancia de que fue privado el damnificado por el acto ilícito, y que en este código se designa por las palabras "pérdidas e intereses'". Asimismo, al regular los daños e intereses en las obligaciones que no tienen por objeto sumas de dinero, el artículo 519 ibídem señalaba que "se llaman daños e intereses el valor de la pérdida que haya sufrido, y el de la utilidad que haya dejado de percibir el acreedor de la obligación, por la inejecución de ésta a debido tiempo", y el artículo 520 indicaba que "en el resarcimiento de los daños e intereses sólo se comprenderán los que fueren consecuencia inmediata y necesaria de la falta de cumplimiento de la obligación".

En relación a la pérdida de chance y el lucro cesante en el Código Civil y Comercial, ver Márquez, J. F. Distinción entre chance y lucro cesante. Su recepción en el Código Civil y Comercial. Revista Jurídica Argentina La Ley. Responsabilidad Civil y Seguros, 2015-I, 5 ss. 
al prestador todos los gastos y trabajos realizados y la utilidad que hubiera podido obtener. El juez puede reducir equitativamente la utilidad si la aplicación estricta de la norma conduce a una notoria injusticia"52.

Sin embargo, hay otras normas que no aclaran el alcance de la reparación, como el artículo 730, inciso c) del Código Civil y Comercial que establece que la obligación da derecho al acreedor a "obtener del deudor las indemnizaciones correspondientes" 53 .

En este contexto, cabe advertir que si el artículo $17 \mathrm{CN}$ estableciera la reparación plena, todas las normas infraconstitucionales que no dispongan la reparación del daño emergente y el lucro cesante resultarían contrarias a la norma fundamental. En esta línea, ComAdira creía que el constituyente garantizó el derecho de propiedad sin fijar de antemano cómo debería ser la reparación en el supuesto en que él fuese violado o debiese ceder por razones de bien común. Esta es materia de las "leyes que reglamenten su ejercicio". Leyes que en distintas órbitas han fijado criterios de indemnización atendiendo a criterios lógicos: reparación más amplia en supuestos de antijuricidad y culpabilidad (responsabilidad por actividad ilícita) y limitada en casos de actividad legítima (responsabilidad por actividad lícita), aunque la extensión del quántum dependerá de la reglamentación legal efectuada por el legislador, en el marco de los artículos 14 y $17 \mathrm{CN}$.

Por su parte, Alterini, Ameal y López Cábana opinaban que la expresión 'reparación integral' no quiere decir nada. En tal sentido, manifiestan: "Solo tiene sentido hablar de reparación plena: se entiende por tal la que coincide con la plenitud propia de cada ordenamiento jurídico, la que se obtiene según lo que cada ordenamiento jurídico atribuye al causante del daño. Eso, y nada más" ${ }^{4}$.

\section{Distinción según la naturaleza del derecho lesionado}

MARIENHOFF opinaba que la amplitud o la extensión de la indemnización dependían fundamentalmente del origen y naturaleza del derecho lesionado por la conducta del Estado. Si tal derecho fuera de origen y naturaleza "común" (civil o comercial), el resarcimiento debe ser integral, comprendiendo tanto

52 Del mismo modo, el artículo 1638 disponía que "el dueño de la obra puede desistir de la ejecución de ella por su sola voluntad, aunque se haya empezado, indemnizando al locador todos sus gastos, trabajo y utilidad que pudiera obtener por el contrato. Empero, los jueces podrán reducir equitativamente la utilidad a reconocer si la aplicación estricta de la norma condujera a una notoria injusticia"

53 De igual modo, el artículo 505, inciso $3 \mathrm{CC}$, en cuanto a los efectos de las obligaciones respecto del acreedor, indicaba que le da derecho "para obtener del deudor las indemnizaciones correspondientes".

54 Alterini, A.A.; Ameal, O. J. y López Cábana, R. M. Derecho de Obligaciones Civiles y Comerciales. Buenos Aires: Abeledo-Perrot, 1995. 
el daño emergente como el lucro cesante. En cambio, si fuera de origen y naturaleza "administrativo", la indemnización sólo debe comprender el daño emergente ${ }^{55}$.

Entendía que en nuestro sistema la reparación del lucro cesante solo procedía - por principio- cuando la naturaleza del derecho agraviado era de naturaleza común (civil o comercial), pero no cuando era de naturaleza administrativa. Esto último, como criterio general, se refiere a la actividad lícita del Estado, en el que se excluye el pago de lucro cesante, toda vez que así lo requería la justicia distributiva, poniendo como ejemplo las distintas normas en el derecho público que no reconocen el pago del lucro cesante. En cambio, cuando es por actividad ilícita, también existe la obligación de resarcir el lucro cesante.

El autor mencionado señalaba que el criterio antes expuesto también era de estricta vigencia en materia de reparación de daños y perjuicios derivados de la revocación por motivos de oportunidad, mérito y conveniencia, de derechos nacidos con motivo de un acto o de un contrato administrativo, porque el fundamento de ese tipo de revocación, o sea, el interés publico o general, es substancialmente igual al de expropiación y al de ciertas requisiciones (utilidad pública). Por lo tanto, obvias razones de congruencia requieren soluciones iguales.

Así, los de naturaleza administrativa se rigen por criterios de justica distributiva, que es la justicia establecida por el Estado. Y en este tipo de justicia no rige el principio de reparación integral de daños y perjuicios. Por lo tanto, si se reconociera a título de indemnización o resarcimiento lo desmesurado, trasuntaría una actitud que desvirtúa la idea de justicia, porque quiebra el equilibrio pleno que ella supone. Entonces, reconocer lo desmesurado o excesivo a favor del cocontratante vulnera la noción de justicia y desconocimiento de que tal tipo de prerrogativa le pertenece por principio al Estado ${ }^{56}$.

En este orden de ideas, y refiriéndose concretamente a un caso de extinción de un derecho de origen y naturaleza administrativo, operada por vía de revocación por razones de oportunidad, mérito o conveniencia, puntualizó que la indemnización sólo comprendía el daño emergente, no así el lucro cesante. Esto así, toda vez que el fundamento mismo de la potestad estatal para extinguir sus actos administrativos creadores de derechos revocados por las razones antes enunciadas, se halla ínsito en el propio fin esencial del Estado, o sea, la protección del interés general o público ${ }^{57}$.

Asimismo, señaló que las disposiciones legales sobre expropiación se aplican en materia de revocación por razones de oportunidad, mérito y conveniencia, no por analogía, sino porque ese es también el régimen propio y

55 MARIENHOFF. Nuevamente acerca del lucro cesante, cit., p. 1080.

56 Ibíd., 1085.

57 MARIENHOFF. El lucro cesante en las indemnizaciones..., cit., 949. 
directo de este tipo de revocación de actos o contratos administrativos. Eso es así porque la revocación por dichos motivos no es otra cosa que la expropiación referida específicamente a la extinción de un derecho de origen y naturaleza administrativo, y recuerda que ese modo de extinguir tales derechos constituye una potestad propia de la Administración Pública.

Sin embargo, es dable destacar que aquellas consideraciones se refieren siempre al supuesto de una revocación lícita, no viciada, válida. Ya que en caso de que se declare la nulidad de la revocación, esta debe ser integral, toda vez que deriva de un actuar ilícito del Estado ${ }^{58}$.

\section{b. Postura favorable al reconocimiento del daño emergente y el lucro cesante}

En una postura contraria a la de MARIENHOFF y COMADIRA, BIANCHI considera que el Estado debe, al igual que todo contratante, otorgar un resarcimiento pleno, cuando su obrar ha producido un perjuicio, aunque dicha conducta no sea precisamente antijurídica. Al comentar el fallo "Sánchez Granel" indicó que el pronunciamiento mayoritario se ajustaba a la más moderna corriente jurídica según la cual ya no debía considerarse al Estado como un ente superior a las restantes personas del derecho y eximirlo, por tanto, de obrar debidamente y conforme a las mismas reglas a las que traban relaciones jurídicas con él, ya sean contractuales o extracontractuales ${ }^{59}$.

Por su parte, CASSAGNE ha postulado recientemente que "el principio de la justa indemnización conduce a que las diferentes formas de restitución por daños causados por la actividad legítima del Estado, ya sea ésta de naturaleza administrativa (unilateral, contractual o reglamentaria) como legislativa, implican siempre restablecer la igualdad en proporción a las cosas y si bien, en un acto jurídico o contrato, pueden coexistir relaciones de justicia conmutativa con las derivadas de un modelo distributivo, resulta equivocado identificar el derecho público con la justicia distributiva, dejando inaplicables las reglas de la restitución propias de la justicia conmutativa que son las únicas que permiten recomponer la desigualdad y cumplir de ese modo con el principio de igualdad ante las cargas públicas (art. 16 C.N.) y con el consiguiente deber de reparar, dado que no es justo que una persona sufra un sacrificio especial cuando no está obligada a soportar el daño"60.

A su vez, Perrino reconoce que en ninguna de las disposiciones de la Ley Fundamental ni de los tratados internacionales que por el artículo 75 , inciso

58 Ibíd., 956.

59 Bianchi, A. B. Nuevos alcances en la extensión de la responsabilidad contractual del Estado. Revista Jurídica Argentina El Derecho, t. 111, 550.

60 Cassagne, J. C. El principio general de la justa indemnización en la responsabilidad del Estado, ¿justicia conmutativa o distributiva? Revista Jurídica Argentina La Ley, 14/9/2015, $1 \mathrm{ss}$. 
22 , tienen jerarquía constitucional se enuncia en forma expresa el derecho a percibir una indemnización integral de todos los perjuicios que pueda sufrir un afectado por una medida estatal dañosa (entre ellos, el lucro cesante), aunque sostiene que ello no es razón suficiente para desconocer el derecho a su reconocimiento con base constitucional ${ }^{61}$.

En ese orden de ideas, considera que como regla el lucro cesante no debe ser excluido de la reparación cuando el Estado ocasiona perjuicios por actuaciones lícitas, aunque no quita que pueda ser equitativamente restringido en su extensión, teniendo en consideración las circunstancias de cada caso, ya que así como le parece irrazonable e injusto descartarlo por principio en todos los casos, ya que ello acarrearía el despojo del derecho de propiedad del afectado, también lo estima así reconocerlo sin limitación alguna. Ello es así toda vez que la reparación no puede constituirse en una fuente de beneficios o enriquecimiento para el afectado, quien no podría pretender que se le resarza más que el equivalente de lo que en realidad pierde por la actuación estatal lícita lesiva de sus derechos.

\section{EL CÓDIGO CIVIL Y COMERCIAL}

El 23 de febrero de 2011 fue dictado el Decreto 191/11 ${ }^{[62]}$, que creó la Comisión para la Elaboración del Proyecto de Ley de Reforma, Actualización y Unificación de los Códigos Civil y Comercial de la Nación, que tuvo a su cargo el estudio de las reformas al Código Civil y al Código de Comercio de la Nación que se considerasen necesarias, a fin de producir un texto homogéneo del referido cuerpo normativo. Dicha comisión estuvo integrada por los ministros de la Corte Suprema de Justicia de la Nación Ricardo Luis LoRENZETTi, quien actuó como presidente, y Elena Highton De Nolasco, y por la profesora Aída Kemelmajer de CARLuCCi ${ }^{63}$.

En lo que respecta a la responsabilidad del Estado, en el anteproyecto del Código Civil y Comercial se incluyeron tres artículos dentro del Título v

61 Perrino, P. E. La responsabilidad estatal lícita y la indemnización del lucro cesante. Revista Jurídica Argentina Jurisprudencia Argentina, Doctrina, 11/11/2009. Del mismo autor, La regulación de la responsabilidad por actividad estatal legítima en la ley 26.944. Revista Jurídica Argentina La Ley, Suplemento Responsabilidad Civil y Seguros, 2014-XII, 31 ss .

62 B.O. 28/2/2011.

63 En los considerandos de la medida se señaló que por numerosas leyes especiales se fueron actualizando diversos aspectos de los códigos Civil y Comercial de la Nación, que produjeron una modificación del ordenamiento lógico y de la estructura de principios y reglas existentes en los códigos referidos.

Atento a ello, y sumado a que el sistema de derecho privado fue afectado en las últimas décadas por relevantes transformaciones culturales y modificaciones legislativas, se señaló que se tornó necesario proceder a actualizar y unificar la legislación nacional en materia de derecho privado, a fin de que se elabore una obra que, sin sustituir la legislación especial, contuviera una serie de principios generales ordenadores. 
"De otras fuentes de las obligaciones", Capítulo 1 "Responsabilidad civil", Sección 10. "Supuestos especiales de responsabilidad", refiriéndose a la responsabilidad del Estado por el ejercicio irregular de sus funciones (art. 1764), a la responsabilidad del funcionario y del empleado público (art. 1765) y, por último, a la responsabilidad del Estado por actividad lícita (art. 1766) ${ }^{64}$.

En relación a la responsabilidad del Estado por su actividad lícita, el anteproyecto del Código Civil y Comercial en su artículo 1766 disponía que "el Estado responde, objetivamente, por los daños derivados de sus actos lícitos que sacrifican intereses de los particulares con desigual reparto de las cargas públicas. La responsabilidad sólo comprende el resarcimiento del daño emergente; pero, si es afectada la continuación de una actividad, incluye la compensación del valor de las inversiones no amortizadas, en cuanto hayan sido razonables para su giro".

Se pueden destacar diversas cuestiones de la norma reseñada. En primer lugar, cabe resaltar que el artículo citado deja sentado expresamente que no se debe violar el principio de igualdad reconocido en el artículo $16 \mathrm{CN}$ y, por tanto, no se deben sacrificar intereses de los particulares con desigual reparto de las cargas públicas.

En segundo lugar, cabe poner de relieve que el anteproyecto receptaba el siguiente criterio: en principio, la responsabilidad sólo comprende el resarcimiento del daño emergente, con la exclusión del lucro cesante. Como lo indicaba MARIENHOFF, es el principio que más requiere la justicia distributiva.

Sin embargo, incluía una excepción a tal principio. Se refería al caso en que, si se afecta la continuación de una actividad, el Estado debería compensar el valor de las inversiones que no hayan sido amortizadas. Aunque señalaba que su giro debe haber sido razonable. Es decir, que el juez debería ponderar en el caso concreto esa razonabilidad del giro. Este último criterio se dirige en la misma línea de los últimos precedentes de la Corte Suprema reseñados, "El Jacarandá”, “Zonas Francas Santa Cruz” y "Malma Trading”, en el sentido de que el resarcimiento de ese rubro lucro cesante se acredite con cierto grado de certeza, y por lo tanto, se considere razonable para su giro.

Si bien, como se analizó, en aquellos pronunciamientos el máximo tribunal entendió que sería procedente el resarcimiento del lucro cesante, también concluyó que el rubro no estaba suficientemente acreditado. En este sentido, en el precedente "El Jacarandá" se puso de relieve que no se había probado en el juicio la concreta privación a la actora de ventajas esperadas de acuer-

64 Hemos analizado los textos del anteproyecto del Código Civil y Comercial y del entonces proyecto de ley sobre responsabilidad del Estado en nuestro trabajo "El alcance de la reparación por la actividad lícita del Estado. A propósito del proyecto de Código Civil y Comercial, y del proyecto de ley sobre responsabilidad del Estado". Revista Jurídica Argentina El Derecho, Suplemento Administrativo, 21/05/2014,13-17. Nos parece imprescindible analizar aquí nuevamente la cuestión, teniendo en cuenta que finalmente aquellas normas fueron sancionadas, y tomando en consideración los debates doctrinales suscitados en relación a las normas citadas. 
do a probabilidades objetivas estrictamente comprobadas. Asimismo, en el caso "Zonas Francas Santa Cruz" se indicó que la actora no había acreditado los daños solicitados en concepto de lucro cesante con el grado de certeza necesario para que proceda su reparación. En el mismo sentido se pronunció el máximo tribunal en la causa "Malma Trading" en cuanto manifestó que no se encontraba acreditada la condición de especialidad para la procedencia de la reparación del lucro cesante.

Sin perjuicio de lo expuesto, cabe señalar que el proyecto finalmente remitido por el Poder Ejecutivo Nacional al Congreso de la Nación, que fue sancionado por la Ley $26.994^{[65]}$, modificó los artículos antes mencionados. En tal sentido, el artículo 1764 quedó redactado de la siguiente forma: "Inaplicabilidad de normas. Las disposiciones del Capítulo 1 de este Título no son aplicables a la responsabilidad del Estado de manera directa ni subsidiaria". Por su parte, el artículo 1765 dispone: "Responsabilidad del Estado. La responsabilidad del Estado se rige por las normas y principios del derecho administrativo nacional o local según corresponda".

Asimismo, cabe poner de relieve que el artículo 9 de la Ley 26.994 mencionada indica: "Dispónense como normas transitorias de aplicación del Código Civil y Comercial de la Nación, las siguientes: [...] Cuarta: 'La responsabilidad del Estado nacional y de sus funcionarios por los hechos y omisiones cometidos en el ejercicio de sus funciones será objeto de una ley especial.' (Corresponde a los artículos 1764, 1765 y 1766 del Código Civil y Comercial de la Nación)".

\section{LA LEY SOBRE RESPONSABILIDAD DEL ESTADO}

Asimismo, el Poder Ejecutivo Nacional presentó ante el Congreso de la Nación un proyecto de ley tendiente a regular la responsabilidad del Estado, que fue aprobado por Ley $26.944^{[66]}$.

En su artículo $4 .^{\circ}$ regula específicamente lo atinente a los requisitos de la responsabilidad estatal por actividad legítima. A saber:
a) Daño cierto y actual, debidamente acreditado por quien lo invoca y mensurable en dinero;
b) Imputabilidad material de la actividad a un órgano estatal;
c) Relación de causalidad directa, inmediata y exclusiva entre la actividad estatal y el daño;
d) Ausencia de deber jurídico de soportar el daño;

65 B.O. $8 / 10 / 2014$.

66 B.O. 8/8/2014. Sobre una crítica general a la ley, ver la nota de opinión de nuestra autoría Hacia la desaparición de la responsabilidad del Estado. El Cronista Comercial, 4/7/2014, 14. 
e) Sacrificio especial en la persona dañada, diferenciado del que sufre el resto de la comunidad, configurado por la afectación de un derecho adquirido.

Asimismo, en su artículo 5. ${ }^{\circ}$ se determina:

La responsabilidad del Estado por actividad legítima es de carácter excepcional. En ningún caso procede la reparación del lucro cesante.

La indemnización de la responsabilidad del Estado por actividad legítima comprende el valor objetivo del bien y los daños que sean consecuencia directa e inmediata de la actividad desplegada por la autoridad pública, sin que se tomen en cuenta circunstancias de carácter personal, valores afectivos ni ganancias hipotéticas.

Los daños causados por la actividad judicial legítima del Estado no generan derecho a indemnización.

En este contexto cabe señalar que la norma pone fin a una salvedad reiterada en la jurisprudencia, respecto a la ausencia de una norma que regule expresamente el alcance de la reparación en la actividad lícita del Estado. En efecto, como se ha analizado, en el fallo "Cantón" se hacía mención a que, "ante la falta de normas expresas sobre el punto", el modo de responder por la actividad del Estado mencionada era el establecido en instituciones análogas (art. $16 \mathrm{CC}$ ), aceptándose que la expropiación era la que guardaba mayor semejanza. En esta misma línea, en el caso "Motor Once" en el dictamen de la procuradora fiscal, y en el caso "El Jacarandá" en el voto de la doctora Highton DE Nolasco, se señaló que "ante la ausencia de una solución normativa singularizada para este tipo de responsabilidad estatal" debía recurrirse a los principios de leyes análogas. De esta forma, la norma supera la discusión sobre la aplicación analógica de la ley de expropiaciones, toda vez que prevé el alcance de la reparación por la actividad lícita del Estado.

Como principio general, la ley citada estipula que la responsabilidad del Estado por actividad legítima es de carácter excepciona ${ }^{67}$. Sobre el punto se ha discrepado con el criterio fijado por la norma de declarar la excepcionalidad, en tanto "podría justificar un angostamiento de la mira de parte de los magistrados" $"$. A su vez, la ley establece de forma tajante que en ningún caso procede la reparación del lucro cesante. Sobre el particular se

67 Sobre el punto, ABERASTURY afirma que si bien la ley de responsabilidad del Estado limita el alcance de la reparación en el caso de una actividad lícita, la Corte Suprema en los casos "Sánchez Granel”, "Jucalán Forestal” y "Malma Trading” extendió la indemnización al lucro cesante, y no lo limitó al daño emergente (ABERASTURY, P. La nueva Ley de Responsabilidad del Estado. Revista Jurídica Argentina La Ley, ADLA, 2014-25, 18 ss.).

68 Márquez, J. y CALderón, M. R. Responsabilidad del Estado por actividad legítima. 
ha dicho que la exclusión del lucro cesante y del daño moral es cuestionable porque atenta contra el principio de reparación integral del daño prevista en el artículo 1083 del antiguo Código Civil, y por ser contrario a la doctrina judicial sentada por la Corte Suprema ${ }^{69}$. Asimismo, se ha indicado que no debería negarse en forma genérica y dogmática el derecho al reclamo de la reparación del lucro cesante en los casos que pudieran suscitarse con motivo de la actividad estatal legítima ${ }^{70}$.

Por otro lado, al igual que el artículo 10 de la Ley 21.499, la ley determina que la indemnización sólo comprende el valor objetivo del bien y los daños que sean consecuencia directa e inmediata de la actividad desplegada por la autoridad pública. Asimismo, dispone que no se tomarán en cuenta las circunstancias de carácter personal, valores afectivos ni ganancias hipotéticas.

\section{CONCLUSIONES}

En el presente trabajo se ha analizado el alcance de la reparación por la actividad legítima del Estado, en concreto, si es procedente, además del daño emergente, el rubro lucro cesante.

Se ha hecho referencia a la jurisprudencia de la Corte Suprema sobre el punto. De este modo, en los precedentes "Corporación Inversora Los Pinos" (1975), "Canton" (1979) y "Motor Once" (1989) consideró que no corresponde el resarcimiento del lucro cesante en los supuestos de responsabilidad del Estado por su actividad lícita. Por el contrario, lo admitió en los precedentes "Sánchez Granel” (1984) y "Juncalán Forestal” (1989). Con posterioridad, en los casos "El Jacarandá" (2005) y "Zonas Francas" (2009) afirmó que no hay fundamento para limitar la reparación al daño emergente con exclusión del lucro cesante, aunque en aquellos casos entendió que no se había acreditado los daños en concepto de lucro cesante. Finalmente, en el precedente "Malma Trading" (2014) el máximo tribunal sostuvo que no se encontraba acreditada la condición de especialidad del daño para admitir la responsabilidad del Estado por su actividad lícita.

Asimismo, se hizo referencia a las posturas doctrinales contrarias y favorables al reconocimiento del lucro cesante algunos criterios doctrinales al respecto. En relación al primer criterio, se tuvo especial consideración al planteo respecto de la "fuerza expansiva" de la ley de expropiaciones. Asimismo, se efectuó una reseña del alcance de la reparación en diversas

Excepcionalidad, resarcimiento y actividad judicial. Revista Jurídica Argentina La Ley, t. 2014C, p. 932 .

69 Pirota, M. D. La responsabilidad del Estado en el Código Civil y Comercial y en la Ley sobre Responsabilidad del Estado. Revista Jurídica Argentina La Ley, Doctrina Judicial, 29/10/2014, 95 ss.

70 Galli Basualdo, M. El lucro cesante en la responsabilidad del Estado por actividad legítima. Revista Jurídica Argentina La Ley, t. 2014-B, 672. 
normas de derecho público y privado, y se estudió la distinción propuesta por MARIEnhoff respecto a la naturaleza del derecho lesionado. Finalmente, se analizaron las disposiciones del Código Civil y Comercial, y de la ley sobre responsabilidad del Estado.

El tema en análisis suscita diversas opiniones, y la Corte Suprema ha intentado encausar un instituto que no parece admitir fácilmente soluciones generales ${ }^{71}$. Si bien la solución concreta de la cuestión dependerá esencialmente del derecho positivo del respectivo país o lugar-cuestión actualmente establecida en la ley sobre responsabilidad del Estado-, se considera más acorde a la justicia distributiva que, en principio, el Estado no debe responder por el lucro cesante por los daños ocasionados en su accionar lícito.

Se ha dicho que si el Estado respondiera por el lucro cesante ilimitado cada vez que lleva a cabo una actividad lícita que provoca daños, pronto se agotarían los recursos fiscales, y hasta podrían no llegar a resarcirse las hipótesis comunes de responsabilidad estatal, esto es, por lo actos ilícitos. Lo que constituiría una solución disvaliosa, pues no resultaría justo que el Estado se convierta en un eterno asegurador de todos los daños y menos todavía de los provocados al perseguir una finalidad de interés público, en una medida mayor que el valor objetivo de la cosa o derecho afectado y de los perjuicios que sean consecuencia directa e inmediata de la expropiación o de la revocación por razones de oportunidad, mérito y conveniencia ${ }^{72}$.

Sin perjuicio de ello, consideramos disvaliosa la solución propiciada por la ley sobre responsabilidad del Estado. Por el contrario, creemos que mayor corrección presentaba la redacción del anteproyecto del Código Civil y Comercial en lo que se refiere al alcance de la reparación por parte del Estado por su actividad lícita. Cabe afirmar que, como principio, la reparación por el actuar lícito del Estado debe limitarse al daño emergente. Sin embargo, consideramos que en ciertas circunstancias particulares cabe exceptuar dicho principio general en tanto se podría llegar a situaciones injustas. Como ejemplo, puede citarse la excepción estipulada en el anteproyecto del Código Civil y Comercial que afirmaba que "si es afectada la continuación de una actividad, incluye la compensación del valor de las inversiones no amortizadas, en cuanto hayan sido razonables para su giro cuando se afecte la continuación de una actividad".

De esta forma, consideramos que los jueces deberían ponderar en cada caso el alcance de la indemnización, aunque teniendo en cuenta que el principio general es la exclusión del rubro lucro cesante. De este modo, en ciertos casos podría reconocerse el lucro cesante, toda vez que en algunas

71 Comadira, ob. cit., p. 443.

72 MACAREL. Una vuelta de tuerca en la jurisprudencia de la Corte: el alcance de la doctrina del caso ‘Sánchez Granel'. Revista Jurídica Argentina La Ley, t. 1989-D, 25. 
situaciones, si se reconociera únicamente el daño emergente, se arribaría a una notoria injusticia ${ }^{73}$.

Sin perjuicio de lo expuesto, y en la línea de lo que ha expuesto la Corte Suprema en los casos "El Jacarandá", "Zonas Francas" y "Malma Trading", cabe destacar que una carga que no debe obviar quien pretende el resarcimiento integral es probar y acreditar el daño en concepto de lucro cesante. En esta línea, cabe recordar que el artículo 377 del Código Procesal Civil y Comercial establece que cada parte soporta la prueba de los hechos a los que atribuye la producción del efecto jurídico que pretende. Sobre el punto ha señalado el máximo tribunal que la actividad probatoria constituye, como toda carga procesal, un imperativo del propio interés. Esa actividad procesal es la encargada de producir el convencimiento o certeza sobre los hechos controvertidos y supone un imperativo del propio interés del litigante quien a su vez puede llegar a obtener una decisión desfavorable en el caso de adoptar una actitud omisiva ${ }^{74}$. Asimismo, el alto tribunal ha puesto de relieve que quien invoca ciertos hechos como fundamento de su pretensión tiene la carga de acreditarlos, y si no logra cumplir con esa carga mediante la actividad probatoria desarrollada durante el juicio, corre el riesgo de que su acción sea rechazada ${ }^{75}$.

Finalmente, no puede olvidarse -como afirmaba el artículo 1766 del anteproyecto del Código Civil y Comercial- que el Estado debe responder por los daños derivados de sus actos lícitos al sacrificar el interés de los particulares con desigual reparto de las cargas públicas. Por lo tanto, consideramos que si en un caso particular se encuentra debidamente acreditado el daño en concepto de lucro cesante, el juez podría declarar la inconstitucionalidad del artículo 5 de la ley sobre responsabilidad del Estado a fin de resguardar la supremacía constitucional, ya que de lo contrario, esto es, de no repararse adecuadamente los daños ocasionados por el obrar lícito del Estado, podrían afectarse los principios de igualdad y propiedad reconocidos constitucionalmente.

\section{BIBLIOGRAFÍA}

Aberastury, Pedro. La nueva Ley de Responsabilidad del Estado. Revista Jurídica Argentina La Ley. ADLA, 2014-25, 18 ss.

Alterini, Atilio Aníbal; Ameal, Óscar José y López Cábana, Roberto M. Derecho de Obligaciones Civiles y Comerciales. Buenos Aires: Abeledo-Perrot, 1995.

73 Ver, p. ej., el voto del doctor FAYT en el caso "Juncalán Forestal".

74 CSIN, "Kopex Sudamericana SAI. y C. c/ Buenos Aires, Provincia de y otros s/ daños y perjuicios", 19/12/1995 (Fallos: 318:2555).

75 CSJN, "Feuermann, Roberto c/ EN - ANA - s/ daños y perjuicios", 29/4/2008 (Fallos: $331: 881)$. 
Bianchi, Alberto B. Nuevos alcances en la extensión de la responsabilidad contractual del Estado. Revista Jurídica Argentina El Derecho, t. 111, 550.

Boretto, Mauricio. Responsabilidad del Estado por actividad lícita: obra pública e inundaciones. ¿La reparación del 'lucro cesante'? Revista Jurídica Argentina El Derecho, 4/11/2015, 1 ss.

Caputi, María Claudia. La responsabilidad del Estado en Argentina. Una reseña panorámica de sus principales cuestiones en la actualidad. Revista de Derecho Público. Editorial Jurídica Venezolana. Vol. 117, enero-marzo 2009.

Cassagne, Juan Carlos. El principio general de la justa indemnización en la responsabilidad del Estado, ¿justicia conmutativa o distributiva? Revista Jurídica Argentina La Ley. 14/9/2015, 1 ss.

Catalano, Mariana. Nueva Ley de Responsabilidad del Estado. Análisis de su articulado en relación a la jurisprudencia de la Corte y al proyecto de la Comisión de Reformas al Código Civil. Revista Jurídica Argentina La Ley. Suplemento Responsabilidad Civil y Seguros, 2014-XII, 5 ss.

Comadira, Julio R. Derecho Administrativo. Buenos Aires: Abeledo-Perrot, 1996.

Coviello, Pedro J. J. La responsabilidad del Estado por su actividad lícita. Revista Jurídica Argentina El Derecho. Suplemento Administrativo, 29/8/2000.

Estrada, JuAn RAmón De. Responsabilidad del Estado por actos legislativos y discrecionales (fundamentos y límites de la responsabilidad por actividad estatal conforme a derecho). Revista Jurídica Argentina El Derecho, t. 102, 839.

Galli Basualdo, Martín. El lucro cesante en la responsabilidad del Estado por actividad legítima. Revista Jurídica Argentina La Ley, t. 2014-B, 672.

Gelli, María Angélica. Lectura constitucional de la Ley de Responsabilidad del Estado. Revista Jurídica Argentina La Ley, t. 2014-E, 659.

Lima, Fernando Juan y Sama, Miguel Alberto. La responsabilidad del Estado por su accionar lícito: los requisitos para su procedencia. Revista Jurídica Argentina El Derecho, t. 150, 97.

Macarel. Una vuelta de tuerca en la jurisprudencia de la Corte: el alcance de la doctrina del caso 'Sánchez Granel'. Revista Jurídica Argentina La Ley, t. 1989-D, 25.

Marienhoff, Miguel S. El lucro cesante en las indemnizaciones a cargo del Estado (lo atinente a la revocación de actos o contratos administrativos por razones de oportunidad, mérito o conveniencia). Revista Jurídica Argentina El Derecho, t. 114, 949.

Marienhoff, Miguel S. Nuevamente acerca del lucro cesante en las indemnizaciones a cargo del Estado. Revista Jurídica Argentina La Ley, t. 1991-C, 1080.

Márquez, José Fernando. Distinción entre chance y lucro cesante. Su recepción en el Código Civil y Comercial. Revista Jurídica Argentina La Ley. Responsabilidad Civil y Seguros, 2015-I, 5 ss. 
Márquez, José Fernando y Calderón, Maximiliano Rafael. Responsabilidad del Estado por actividad legítima. Excepcionalidad, resarcimiento y actividad judicial. Revista Jurídica Argentina La Ley, t. 2014-C, 932.

Perrino, Pablo E. La responsabilidad estatal lícita y la indemnización del lucro cesante. Revista Jurídica Argentina Jurisprudencia Argentina, Doctrina, 11/11/2009.

Perrino, Pablo E. La regulación de la responsabilidad por actividad estatal legítima en la ley 26.944. Revista Jurídica Argentina La Ley. Suplemento Responsabilidad Civil y Seguros, 2014-XII, 31 ss.

Pirota, Martín Diego. La responsabilidad del Estado en el Código Civil y Comercial y en la Ley sobre Responsabilidad del Estado. Revista Jurídica Argentina La Ley. Doctrina Judicial, 29/10/2014, 95 ss.

Pizarro, Ramón D. Responsabilidad del Estado por actos lícitos. Consecuencias 'normales' y 'anormales' de su actividad. Revista Jurídica Argentina La Ley, t. 2014-C, 262.

Ylarri, Juan Santiago. El alcance de la reparación por la actividad lícita del Estado. A propósito del proyecto de Código Civil y Comercial, y del proyecto de ley sobre responsabilidad del Estado. Revista Jurídica Argentina El Derecho. Suplemento Administrativo, 21/05/2014, 13-17.

Ylarri, Juan Santiago. Hacia la desaparición de la responsabilidad del Estado. El Cronista Comercial, 4/7/2014, 14.

\section{Jurisprudencia de la Corte Suprema de Justicia de la Nación}

"Agencia Marítima Rioplat SA. c/ cap. y/o arm. y/o prop. bq. Eleftherotria s/ ordinario", 10/12/1992 (Fallos: 315:2865).

“Cachau, Oscar José c/ Bs. As. Pcia. de s/ daños y perjuicios”, 16/6/1993 (Fallos: 316:1335).

“Canton, Mario Elbio c/ Nación”, 15/5/1979 (Fallos 301:403).

"Columbia S.A. de Ahorro y Préstamo para la Vivienda c/ Banco Central de la República Argentina", 19/5/1992 (Fallos: 315:1026).

“Cooperativa Ltda. de Enseñanza, Instituto Lomas de Zamora c/ Nación”, 1975 (Fallos: 291:359).

“Corporación Inversora Los Pinos S.A. c/ Municipalidad de la Ciudad de Buenos Aires", 22/12/1975 (Fallos: 293:617).

“De Milo, Ernesto N. c/ Nación”, 1967 (Fallos: 267:247).

"Eduardo Sánchez Granel Obras de Ingeniería S.A.I.C.F.I. c/ Dirección Nacional de Vialidad", 20/9/1984 (Fallos 306:1409).

"El Jacarandá S.A. c/ Estado Nacional s/ juicios de conocimiento", 28/5/2005 (Fallos 328:2654).

"Feuermann, Roberto c/ EN - ANA - s/ daños y perjuicios", 29/4/2008 (Fallos: 331:881). 
"Galanti, Carlos Alberto c/ Municipalidad de la Ciudad de Buenos", 22/12/1987 (Fallos: 310:2824).

"Jucalán Forestal, Agropecuaria SA. c/ Buenos Aires, Provincia de s/ daños y perjuicios", 23/11/1989 (Fallos 312:2266).

Kopex Sudamericana SAI. y C. c/ Buenos Aires, Provincia de y otros s/ daños y perjuicios" 19/12/1995 (Fallos: 318:2555).

“Kremer y Kramer Hnos. c/ Nación”, 1967 (Fallos: 268:228).

"Laplacette, Juan su sucesión y otros c/ Prov. de Bs. Aires”, 1943 (Fallos: 195:66).

“Lovardo, Salvador c/ Municipalidad de Vicente López”, 15/3/1983 (Fallos: 305:321).

"Malma Trading S.R.L. c/ Estado Nacional-Ministerio de Economía y Obr. y Serv. Publ. s/ proceso de conocimiento", 15/5/2014 (causa M.1378. XLVII, ROR).

"Motor Once, SAC e I. c/ Municipalidad de la Ciudad de Buenos Aires", 9/5/1989 (Fallos: 312:649).

“Neville, Jorge Andrés c/ Banco Popular Argentino S.A.”, 1986 (Fallos: 308:1361).

“Pistone, Ciro Alberto c/ Estado Nacional s/daños y perjuicios”, 29/5/2007 (Fallos: 330:2464).

"Román SAC. c/ Estado Nacional (Ministerio de Educación y Justicia s/ cobro de pesos", 13/10/1994 (Fallos: 317:1233).

“Santina, Felipa N. c/ Caceres, Néstor C.”, 1978 (Fallos: 300:61).

“Serradilla, Raúl Alberto c/Mendoza, Provincia de y otro s/ daños y perjuicios”, 12/6/2007 (Fallos: 330:2748).

“Tejedurías Magallanes S.A. c/ Administración Nacional de Aduanas”, 19/9/1989 (Fallos: 312:345).

"Videla Cuello, Marcelo suc. de c/ La Rioja, Prov. de s/ daños y perjuicios", 16/3/1989, (Fallos: 312:316).

"Viento Norte de herederos de Bruno Corsi SRL. c/ Santa Fe, Provincia de s/ ordinario", 4/3/1997 (Fallos: 320:266).

"Zonas Francas Santa Cruz S.A. c/ Estado Nacional - P.E.N. - Dto. 1583/96 s/ daños y perjuicios", 9/6/2009 (Fallos 332:1367). 